\title{
Role of Riverine Sediment in Adsorption of Heavy Metals at Krishna River in Sangli District, Maharastra (India)
}

\author{
S. A. Manjare \\ Department of Zoology, Jaysingpur College, Jaysingpur
}

\begin{abstract}
The present attempt has made to study role of reverine sediment in adsorption of heavy metals at Krishna river in Sangli District, Maharashtra (India). The study revealed that the potability of water from January 2013 to December 2013. Some physicochemical parameters were considered such as temperature, turbidity, transparency, total solids, pH, dissolved oxygen, free carbondioxide, hardness, chloride, alkalinity, phosphates and nitrates were studied.
\end{abstract}

Keywords: Heavy metals, sediments, adsorption, Krishna River

\section{Introduction}

Environment is degraded due to man's economic exploitation of nature; the crisis is due to greed, lack of insight and narrow scientism. It is due to ignoring the chemical nature of biosphere and spiritual nature of man. Man's ability to modify the environment (pollute the environment) increases faster than his ability to foresee the effect of the activity. The cycles in the ecosystems like energy cycle, material cycle and geochemical cycle are getting completely polluted. Inappropriate disposal and accidental release of toxic and hazardous substances into environment from chemical and industrial activities have created environmental and public health problems all over the world. River ecosystem and its monitoring are very important problems because of the uses of river waters for various purposes. River water pollution is another important discipline at moment (Kataria, 1994). Polluted

The discharge of effluents containing heavy metals into the river may be the reason for higher concentration of metals. In sewage sludge heavy metals may be bound to small particles consisting mostly of organic matter. The destructive and harmful effects of heavy metal pollution are substantiated species of diversity and low abundance of fauna and flora. The alarming sign of heavy metal contamination in river water was observed. Even at infinite low levels, heavy metals get adsorbed in the bottom sediments affecting benthos, and hence they are regarded as potential pollutants in aquatic ecosystems. Environmental persistence, having toxicity at low concentrations and their ability to incorporate in food chain. Biological transfer of heavy metals through food chain is of significant interest since these are more concentrated within the tissue.

The accumulation of heavy metals in the river sediments due to discharge of industrial effluents and sewage has serious implications for the biota and human beings. Depending upon a number of factors, the trace metals may remain immobilized or become available for uptake of biota and their tissue concentration as well as the metabolic effects of different trace metals. Finally, critical analysis of both chemical and biological characteristics indicate that, at present the impact of the metals may not be serious but in future their concentrations may increase due to continuous entry effluents from industries and bring drastic changes in river water quality and biological spectrum. The continuous monitoring of these environments is essential for checking the levels of various metals entering through different types of effluents or pollutants.

The present study deals with the heavy metal load in the sediments samples of Krishna river at Sangli, Haripur and Ankali such as Nickel, Zinc, Lead and Aluminium.

\section{Material and Methods}

The present investigation was carried out during the year January 2013 to December 2013. The water and Sediment samples were collected in plastic can and polythene bags respectively, after fortnightly interval from the selected sampling stations (Sangli, Haripure \& Ankali). Then the samples were brought to the laboratory for further analysis. The sediment samples were air dried, pulverized in a mortar and sieved through a standard sieve of 0.5 to $0.6 \mathrm{~mm}$. the sieved samples were analyzed for detection of heavy metals. The required sediment samples were digested in $50 \mathrm{ml}$ perchloric acid and $50 \mathrm{ml}$ Nitric acid in 1:1 ratio for $48 \mathrm{hrs}$. The digested samples were filtered and the filtrate was subjected for detection of heavy metals by atomic Absorption Spectrophotometer and values were expressed in ppm. The water samples were directly subjected to analysis for heavy metals. Lithnor, G. (1975), Trivedy and Goel, 1987; Lind, 1974.

\section{Result and Discussion}

The present investigation was carried out during the year January 2013 to December 2013. The water and sediment samples were analyzed for heavy metal concentration during different seasons like winter, summer and monsoon i.e. in the months of January, May and July, 2013. The results are expressed in ppm in the table No. for sediment samples. However, heavy metals were not observed in water samples throughout the year. 


\section{International Journal of Science and Research (IJSR) \\ ISSN (Online): 2319-7064 \\ Index Copernicus Value (2013): 6.14 | Impact Factor (2014): 5.611}

The detection of metals such as $\mathrm{Zn}, \mathrm{Ni}, \mathrm{Pb}$ and $\mathrm{Al}$ from sediment samples at three different stations showed that Zinc concentration in the sediments in the Krishna river was higher at Sangli during winter (72 ppm) and in summer (66.7 ppm) while at Haripur in monsoon (63.5 ppm) as compared to other two stations. Similarly these values were maximum during winter as compared to summer and monsoon. The concentration of Zinc recorded during present study is much more higher than the ISI standard (15 ppm).

The concentration of Nickel in sediments of Krishna river was higher at Sangli during winter, summer and monsoon $(0.003 \mathrm{ppm}),(0.004 \mathrm{ppm})(0.002 \mathrm{ppm})$ as compared to Haripur and Ankali stations. While concentration of Nickel was higher in summer (0.004 ppm) at Sangli. These values are below permissible level when compared with ISI standard.

The content of Lead in sediments of Krishna river was maximum(0.008 ppm) (0.009 ppm) (0.005 ppm) at Sangli during winter, summer and Monsoon. In general concentration of Lead was higher at Sangli as compared to Haripur and Ankali. These values are compared with ISI standard $(0.1 \mathrm{ppm})$. These values are below permissible level.

Concentration of Aluminium in sediment of Krishna river was higher at Sangli during winter $(0.085 \mathrm{ppm})$ and in summer $(0.083 \mathrm{ppm})$ where as at Haripur in monsoon $(0.063 \mathrm{ppm})$ as compare to Ankali stations.

The present study clearly indicates that, although the heavy metals were noted from sediment samples, where these were totally absent in the water samples showing cent percent adsorption of heavy metals in sediments from water. High concentration of trace metals in the sediments shows that, the sediments are important reservoir of these contaminants in the riverine system. The role of sediments in adsorption of cations has been demonstrated in a number of studies on rivers (Mani, et.al, 1989, Ayyavoo, 1989, Mariatry and Hanson, 1989, Kakulu, et. al; 1987). The high organic matter content, sulphides and alkalinity also contributed to the high adsorption rate in the sediments.

Trace metal analysis of textile mill effluents, sediments and water of river Khan and Kshipra (1970), showed high concentration of $\mathrm{Zn}, \mathrm{Pb}$ and $\mathrm{Hg}$ in sediments effluents and lower values in water. The concentration of trace metals were found in following order in effluents: $\mathrm{Fe}>\mathrm{Zn}>\mathrm{Cu}>$ $\mathrm{Cr}>\mathrm{Cd}>\mathrm{Pb}>\mathrm{Hg}$. Sediments: $\mathrm{Fe}>\mathrm{Zn}>\mathrm{Cu} \mathrm{Cr}>\mathrm{Pb}>\mathrm{Cd}$ $>\mathrm{Hg}$. Higher concentrations were usually obtained in the upstream regions. Pure textile dyes are the major source of all these metals.

The concentration range of other metals at various sampling sites were: $\mathrm{Zn}-12$ to $175 \mathrm{mg} / \mathrm{Kg}$, and $\mathrm{Hg} 2.5$ to $5.4 \mathrm{mg} / \mathrm{kg}$. These concentrations were generally low during July (Ganasan, 1971)
Table 1: Metal concentrations in sediments from Krishna river (in ppm) Winter (January,2013)

\begin{tabular}{|c|c|l|l|c|}
\hline Metals/ stations & Zinc & Nickel & Lead & Aluminium \\
\hline Sangli & 72 & 0.003 & 0.007 & 0.085 \\
\hline Haripur & 73 & 0.002 & 0.003 & 0.044 \\
\hline Ankali & 54 & 0.001 & 0.001 & 0.050 \\
\hline
\end{tabular}

Table 2: Metal concentrations in sediments from Krishna river (in ppm) Summer (May, 2013)

\begin{tabular}{|c|c|c|c|c|}
\hline Metals/ stations & Zinc & Nickel & Lead & Aluminium \\
\hline Sangli & 66.7 & 0.004 & 0.009 & 0.083 \\
\hline Haripur & 55.6 & 0.003 & 0.005 & 0.068 \\
\hline Ankali & 51.1 & 0.001 & 0.002 & 0.055 \\
\hline
\end{tabular}

Table 3: Metal concentrations in sediments from Krishna river (in ppm) monsoon (August, 2013)

\begin{tabular}{|c|c|c|c|c|}
\hline Metals/ stations & Zinc & Nickel & Lead & Aluminium \\
\hline Sangli & 63.5 & 0.002 & 0.005 & 0.060 \\
\hline Haripur & 40.9 & 0.001 & 0.003 & 0.063 \\
\hline Ankali & 39.2 & 0.001 & 0.0002 & 0.056 \\
\hline
\end{tabular}

\section{Conclusion}

The present study clearly indicates that, although the heavy metals were noted from sediment samples, where these were totally absent in the water samples showing cent percent adsorption of heavy metals in sediments from water. But there concentrations are below the ISI standard except zinc.

\section{References}

[1] Ayyavoo, M. (1989): studies on the metal concentration on Cauvary River.

[2] Ganesan, V. C. (1991): Trace metal concentration in water and sediment of the river Khan and Kshipra (Ujjain, India). Inter. J. Ecol. And Environ. Sci. 17: 225236.

[3] Kataria, H. C. (1994): Heavy metals contamination and pollution in Betwa River. JEP, 15 (1): 34-38.

[4] Kakulu, S. E., O. Osibanjo, S. O. Ajayi (1987) : Comparison of digestion methods for trace metal determination in fish. Intern. J. Environ. Anal. Chem. 30: 209-218.

[5] Lind, O. T (1974): Hand book of common methods in limnology. The C. V. Mosby Co., Saint Louis (USA).

[6] Lithnor, G. (1975): Methods for detection, measurement and monitoring of water pollution, FAO, Rome, PP 41.

[7] Mani, S. S., Sweth Aranyam and S. S. Daevi (1989): An increased level of trace metals in Pazhan Cauvery river water due to domestic sewage pollution. Seminar on Environmental pollution, 30 March, Bangalore.

[8] Moriarty, F. and H. M. Hanson (1989): Heavy metals in sediments of the river Ecchesbourne, Darbishire. Water resources, 22: 475-480.

[9] Trivedy and Goal (1987): Practical methods I Ecology and Environmental Science. 